\title{
Traceability of Information to Identify Nonconformities in the Production Process: Preliminary Study Production Process Optimization
}

\author{
Roberta FERRARI DE SÁa , Osiris CANCIGLIERI JUNIOR ${ }^{\mathrm{a}}$, Anderson Luis \\ SZEJKA $^{\mathrm{a}, 1}$ and Lucy YOSHIDA ${ }^{\mathrm{b}}$ \\ ${ }^{a}$ Pontifical Catholic University of Parana, Curitiba, BR \\ ${ }^{\mathrm{b}}$ NHS Eletronic Systems, Curitiba, BR
}

\begin{abstract}
For a company to compete in today's market, it needs to invest in developing project management tools to help improve its materials, products and production processes, reducing costs and continually improving its activities. This article aims to present the preliminary study performed to implement a custom semantic model in a technology company, which will enable the analysis and diagnosis of the production model to check nonconformities and to track information and materials, aiming at improving its production process and thereby raising its level of competition in the market. The preliminary study corresponds to the first of two phases of project development, which consists of the study carried out in the company to identify improvement needs for implementation of the analysis and diagnosis tool in the production process. For this, a tool development model is being developed with the mapping and the proposal of the model with its implementation strategy. Thus, it was verified that there is a disconnected traceability between the company sectors, information lost at the end of each process step, which eventually increases the time spent in each process phase. To solve this problem, resources were selected that, when integrated, will allow the integration of resources that were not previously connected in the company, in addition to reducing the time spent to close the cycle: connect, collect, analyze and act, making the response of production process activities in real time, seeking the optimization of production.
\end{abstract}

Keywords. Traceability, Production Process, Decision Making

\section{Introduction}

For a company to be competitive, it is necessary to invest in the development of modern project management tools, to improve materials, products and production process, while reducing costs and aiding the continuous improvement of activities. Even with the beginning of the digital revolution, industries have used few technologies for the production routine, leading to few success stories to certify available opportunities [1]. The use of smartphones, tablets and wearables is accelerating the use of mobile manmachine interface technologies, when these technologies are combined with accesss to data and information, they can make operators and teams more productive asa with the access to cloud technology makes it possible to share information more easily and quickly, through a web application [2]. This new context optimizes the control of the

\footnotetext{
${ }^{1}$ Corresponding Author, Mail: anderson.szejka@pucpr.br
} 
manufaafctuirng processes, while using Industry 4.0 insights on productivity, as it considers the monitoring and customization of the production line and simultaneously considering the reduction of costs, contributing to increased competitiveness.

It is believed that the reason for companies to use few technologies for the productive routine, is in most cases, the need for extreme changes, and in some cases changing the entire infrastructure of the production line, which leads to a period of adaptation to the new system, resulting in a decrease in productivity and profits. In this context, a study will be developed, using industry 4.0 concepts, to implement a system to optimize the production process in a brasilian capital and technology company established energy systems sector manufacturing uninterrupted power systems (UPS) and voltage stabilizers, with minimal interference and cost to the company. The project will be developed in 2 phases, starting with the preliminary study, followed by the application of system and the analysis of the results.

This article aims to present the study carried out to develop the towards for a computational tool for managing the production process of a technology company. This article presents the entire study developed to analyze the real needs of the company is gathered so that the requirements for the tool can be determined. The preliminary study of the optimization project of the production process seeks to analyze all the steps and responsible departaments of the company to make a diagnosis, where positive points and opportunities for improvement will be identified, as well as a detailed mapping of each sub-process alongside the integration processes of all activities. During the initial analysis, it was verified the need to develop a computational tool to evaluate the system's model of decay to verify nonconformities and identify opportunities for improvement, where the multiple perspectives involved in the manufacture of the product and the restrictions existing in the company, has compromised the quality of the production process, resulting in higher costs.

In this way, this article will initially present an overview of the Production Process Optimization Project, followed by the research methodology used to support the preliminary study, the results of a bibliographic research to identify tools to support the effective application of the principles of transformation of the raw material and energy in products. The following is an overview of the company's production process, as well as the positive and negative points raised during the field research, resulting in a diagnosis of the current situation of the productive process of the company. the diagnosis was made possible by the field research carried out in the production line to observe, collect, analyze and interpret facts and phenomena, allowing to raise among existing approaches used in the company's factory floor, here called Company Y. With that, it was possible to elaborate a structure of diagnosis and analysis of the production model to determine the solution strategy to be adopted. To conclude, the final considerations will be presented with the application of the first preliminary study phase, followed by the next steps to be taken for the implementation of the Production Process Optimization Project.

\section{Bibliographic Research}

The RBS Roadmap [5] was used partially for the accomplishment of the bibliographical research,. The RBS Roadmap has three phases: input, processing and output. The script was used partially because this study will perform a review of the literature and not a 
more complex research as a systematic review. The input phase, which will be used by this study, has 8 requirements to guide the research, see Table 1.

Table 1. Requirements for the entry phase of the RBS Roadmap (Source: the authors).

\begin{tabular}{|c|c|}
\hline Requirements & Specification \\
\hline Problem & $\begin{array}{l}\text { It is possible to construct a semantic model customized for a company that allows } \\
\text { the analysis and diagnosis of the company's current production model and check } \\
\text { nonconformities, as well as identify opportunities for improvement in the product } \\
\text { production process. }\end{array}$ \\
\hline Goals & $\begin{array}{l}\text { Gather information during the production process using technologies that allow } \\
\text { the fusion of the physical ande digital worlds, to exchange data in real time, } \\
\text { leading to the development of a computational plataform that will gather } \\
\text { information during the production process, characterizing the traceability of } \\
\text { information. To identify nonconformities during the production process and } \\
\text { achieve a faster response to the problem, decreasing the time for decision making, } \\
\text { seeking to provide a holistic follow-up of the process for analyzing the continuos } \\
\text { improvement of production. }\end{array}$ \\
\hline Primary Sources & "Product Engineering "Process Engineering" e "Tool". \\
\hline Search Strings & $\begin{array}{l}\text { Related words: "Appliance". The term "Tool" is at the center of the relationship, } \\
\text { combining with the terms "Product Engineering" and "Process Engineering". }\end{array}$ \\
\hline Inclusion Criteria & $\begin{array}{l}\text { The research was carried out in the CAPAES/MEC periodicals portal. Type of } \\
\text { material: articles; date of publication: last two years; only reviewed articles by } \\
\text { PARES. }\end{array}$ \\
\hline Qualifying Criteria & $\begin{array}{l}\text { Approaches (primary or secondary subject) using support tools for the } \\
\text { development of process engineering. }\end{array}$ \\
\hline Method an Tools & Steps 1 to 4 of the interactive procedure of the RBS Roadmap processing step \\
\hline Schedule & $\begin{array}{l}\text { The survey began in the last quarter of } 2018 \text { and ended in the first quarter of } \\
2019 \text {. }\end{array}$ \\
\hline
\end{tabular}

After defining the requirements to use the script (see table 1), the search was performed in the Portal of Periodicals CAPES/MEC. The portal has a collection with more than 38 thousand titles with full texts and 537 reference bases. Then filter 1 was performed, with the reading of the title, abstract and keywords, totaling 74 articles. With filter 2, the introduction and conclusion were read, reaching the number of 29 articles, ending with filter 3 , with the complete reading of each article, resulting in 10 articles, the listed articles.

The 10 selected articles brought contributions and new questions about innovation, performance improvement and business environment, which will be discussed in the next section.

\section{Results of Bibliographic Research}

With the Bibliographic Research it was possible to see the need to understand the data processes, as key components of the system, from the data capture until its conversion into useful information during the manufacturing processes [1], while offering alternatives for storing a greater number of information for a faster analysis and consequently increase in productivity [14]. In this respect, one can consider the 
information, as "the formatlization of an exchange of one or more project data among stakeholders" [11].

Currently, in the business environment there is a great dynamism and the digital frontier, in the form of IoT, presents itself with great potential for the process industry [1].

The assembly process of the product is one the most important manufacturing activities, where the design, engineering, manufacturing and logistics processes are combined efficiently and economically [7]. Its importance comes from the fact of consuming up to $50 \%$ of the total production time, which represents more than $20 \%$ of the total manufacturing cost [15].

Therefore, manufacturing managers seek to monitor the performance of their operating processes to make the most profitable decisions in the short and long term. However, these decisions are related to na occasional offline analysis or comparisons with simple standards in custom worksheets, taking more time to generate and analyze basic information for effective responses [2]. An analysis of this limited system can cause problems in engineering and business as the system grows, hampering the ability to make good decisions at the system level [16].

In this context, a principle of information management (Closed Circuit Principle) and of recource reuse and integration (Recominant Innovation) were identified in the literature, and were defined as key points to be worked on during the systems development. These principles focus on the improvement of the process already used, considering unconnected resources and the reduction of the management loop without proposing drastic changes that require a linger period for adaptation. In addition, to considering the Mcmullen \& Wiley [2] statement also points to the need to use modeling data convergence with cloud storage in order to enterprise's systems achieve higher quality and data fidelity while minimizing errors and costs.

\subsection{Closed Circuit Principle}

To improve the performance of a process, it is necessary to monitor its performance indicators and to detect any deviation from the defined objective, understanding the process context to evaluate options in order to take the most appropriate corrective action to ensure that the solution is used correctly [2].

Still according to Mcmullen \& Wiley [2], there are four steps of the information management loop: connect, collect, analyze and act, which represent the basis for problem analysis and solution definition throughout the process hierarchy. This structure defines the closed circuit principle, which enables operational excellence by helping business stakeholders to adopt a process focused approach. This principle is key to improving the performance, while it decreases the time spent to close the cycle transforming the activity in real time.

In the current business environment, knowing how to deal with the dynamism of information is becoming a requirement as it offers opportunities for the company, but also threats because of uncertainties and turbulence in the global market, phenomenon attributed to globalization. To seize opportunities and guard agaisnt threats, companies need to develop decision support tools to make decisions more sensible and strategic, tactical and operational. [6]. In this context, it will be considered the closed circuit principle alongside the decrease of latency associated with the reuse and integration of resources that were not previously. 


\subsection{Recombinant Innovation}

The term: recombinant innovation, which means, innovation based on the addition, dissociation and associantion of existing value propositions, using internal and external resources, instead of starting from the beginning [9]. Considering the problem and objective defined for this study, this resource that can and should be considered for the construction of a customized model of analysis and diagnosis of the production model and verification of nonconformities of a company in full activity and competition in the market.

Considering that innovation, the differential that every company seeks to help to excel in the market can be defined as "a discontinuous change and describes a new solution or renewal of an existing solution" [17]. The processes of innovation can be describe in different ways, such as radical innovation, improvement, incremental, ad hoc, recombinant and formalization [18]. In theory, "most innovations are based on recombination" [19], since "almost no innovation is entirely new" [9,20].

In this aspect, this study will consider the positive points in the process of Company $\mathrm{Y}$, to apply the reuse and integration of resources that were previously not connected, rather than designing from the beginning for a rapid and efficient migration to the model of analysis and diagnosis of the production process to be developed.

\section{Field Research}

Field research was carried out in the production line for observation, collection, analysis and iteration of facts and phenomena observed in the approaches carried out on the company's factory floor. A script was used with the activities carried out in the sector and its managers and the information standardized and documented by the company. The positive and negative points found during visitis to the company sectors ar shown in Table 2.

Table 2. Field survey result.

\begin{tabular}{|c|c|c|}
\hline Sector & Positive points & Negative points \\
\hline $\begin{array}{l}\text { Assembly } \\
\text { of product } \\
\text { and by- } \\
\text { product }\end{array}$ & $\begin{array}{l}\text { Cell operators organize production as they see } \\
\text { fit, within the set deadline and goal. Follow-up } \\
\text { of the aid chain drive indexes, OEE (Global } \\
\text { Equipment Efficiency) for calculating cell } \\
\text { efficiency, GBO (Operator Balancing Chart) } \\
\text { and Takt. } \\
\text { According to the indications of the indices can } \\
\text { be realized: Masp (Method of Analysis and } \\
\text { Problem Solving) and Kaisen. }\end{array}$ & $\begin{array}{l}\text { The same information is presented in two } \\
\text { different ways and in two different locations, } \\
\text { both in the system and in the frames, with } \\
\text { manual updates and often outdated in a few } \\
\text { hours. The system update is not real-time. } \\
\text { Only three materials are traceable during the } \\
\text { production process. }\end{array}$ \\
\hline $\begin{array}{l}\text { Mounting } \\
\text { of } \\
\text { transformer }\end{array}$ & $\begin{array}{l}\text { The preparation, separation and supply for } \\
\text { assembly is carried out the previous day with } \\
\text { the schedule sent by the Planning and control } \\
\text { of production. }\end{array}$ & $\begin{array}{l}\text { Problems with copper wire defective and not } \\
\text { traceable during the production process, } \\
\text { causing delay. } \\
\text { The steps of the process are totally handmade, } \\
\text { with control only at the end of the process. } \\
\text { Problem with the brittle spool especially in the } \\
\text { coldest times of the year. }\end{array}$ \\
\hline
\end{tabular}




\begin{tabular}{lll}
\hline Sector & Positive points & Negative points \\
\hline Expedition & $\begin{array}{l}\text { An inventory is carried out weekly to check } \\
\text { stock entry and exit for wrong data } \\
\text { adjustments. }\end{array}$ & $\begin{array}{l}\text { Annotations are made manually in frames to be } \\
\text { passed to the system later - it is not a real-time } \\
\text { update. } \\
\text { Tracking and logging is a times consuming } \\
\text { process and is not automated. } \\
\text { The system usually duplicates the system bug } \\
\text { (IT has already been reported). }\end{array}$ \\
& There is no checklist or alert for overdue tasks. \\
\hline
\end{tabular}

Final tests When it fails, it goes to the repair cell. There is a report to visualize the production defects.
Partial traceability of the product is possible only when defective enters the history on the finished product label.

All communication is by phone, email and daily meetings - none of the communications happen in real time.

\begin{tabular}{lll}
\hline $\begin{array}{l}\text { Assembly } \\
\text { of plates }\end{array}$ & $\begin{array}{l}\text { All boards are inspected and when necessary, } \\
\text { adjustment is done - this entire process is } \\
\text { recorded and traceable. There is an hour to } \\
\text { hour hour with production goals There is a } \\
\text { study for the reduction of setup time and for } \\
\text { the exchange of older machines. }\end{array}$ & $\begin{array}{l}\text { The solder paste has lead, but for this material } \\
\text { to be changed, older machines will need to be } \\
\text { replaced. The notes on the progress of the } \\
\text { production are done in frame, manually and the } \\
\text { system is not updated in real time. }\end{array}$ \\
\hline $\begin{array}{l}\text { There is a study to evaluate the material } \\
\text { conference time. There is another study for } \\
\text { weighing the copper wire rolls that differed } \\
\text { from the information in the purchase orders. }\end{array}$ & $\begin{array}{l}\text { The update in the system does not happen in } \\
\text { real time, being inserted manually both in the } \\
\text { system and in frames in the sector when it is } \\
\text { possible, in the interval between the activities } \\
\text { inventh priority. There is a trace available only to } \\
\text { externally mounted boards are tested when } \\
\text { received. An inventory is conducted weekly. }\end{array}$ & $\begin{array}{l}\text { All communication is by phone, email and } \\
\text { daily meetings - none of the communications } \\
\text { happen in real time, except for a radio } \\
\text { deployed shortly for testing. The system is very } \\
\text { bureaucratic when something happens that } \\
\text { could be solved in a more practical way. }\end{array}$ \\
\end{tabular}

\section{Diagnosis of the production model}

With the field research and survey of the positive and negative points, a diagnostic strutucture of the production model was developed to determine the strategy to be adopted to comply with the objectives and guidelines that govern the company's philosophy. The diagnostic structure helped in the description of the company's activities, production strategies, description of the advantages and possibilities for improvement of each sector and the enumeration of this information regarding the organizational structure, the administrative methods and processes and the product development, in addition to verifying the proximity or distance in relation to the achievement of the company's objectives, which led to the guidelines for putting into practice the theoretical issues raised during the development of this project.

Its objectives are related to cost-benefit and flexibility, however, to check proximity or distance in relation to the achievement of the company's objectives, the objectives related directly or indirectly to the production process of the selected product were considered (table 3). 
Table 3. Summary table of analysis of the diagnosis of the production process (source: the authors).

\begin{tabular}{|c|c|c|c|c|c|c|c|c|}
\hline \multirow[b]{2}{*}{ Diagnosis* } & \multicolumn{7}{|c|}{ Selected Objectives } & \multirow[b]{2}{*}{ 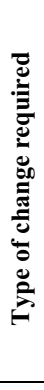 } \\
\hline & 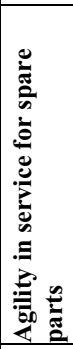 & 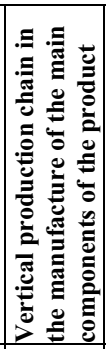 & 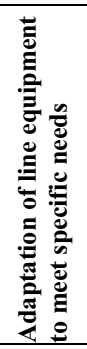 & 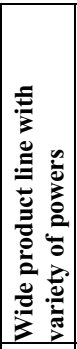 & 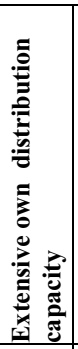 & : & 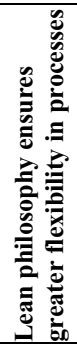 & \\
\hline $\begin{array}{l}\text { System update does not happen in real time; the } \\
\text { information is entered manually into the system } \\
\text { during the intervals between activities; the } \\
\text { information is repeated in tables manually and does } \\
\text { not happen in real time; there is local and } \\
\text { unconnected tracking in some departments; } \\
\text { communication takes place by telephone, e-mail } \\
\text { and daily meetings; emergency drives use radios; } \\
\text { distribution routes have been optimized with wave } \\
\text { distribution. }\end{array}$ & ap & at & 0 & at & at & ap & ap ** & v2 \\
\hline $\begin{array}{l}\text { The material used for welding does not yet follow } \\
\text { RoHS guidelines; annotations are manual and } \\
\text { made. }\end{array}$ & ap & at & ap & 0 & 0 & 0 & ap ** & v3 \\
\hline $\begin{array}{l}\text { Delay in the production process caused by a defect } \\
\text { in the copper wire; copper wire coils are not traced, } \\
\text { making it difficult to identify the supplier or } \\
\text { purchase lot; process carried out with handmade } \\
\text { tools; tests and updates at the end of the process; } \\
\text { problem with brittle parts from some suppliers. }\end{array}$ & ap & at & ap & 0 & 0 & 0 & ap ** & v3 \\
\hline $\begin{array}{l}\text { The registration of production and updating of the } \\
\text { system is done at the end of the process; } \\
\text { registration is done manually. }\end{array}$ & ap & at & ap & 0 & 0 & 0 & ap $* *$ & v3 \\
\hline $\begin{array}{l}\text { The data generated during the process are } \\
\text { presented in two different ways, in two different } \\
\text { places: in the system and in the information boards, } \\
\text { manually and are not updated in real time. Three } \\
\text { materials have traceability throughout the } \\
\text { production process: plate, battery and transformer. }\end{array}$ & ap & at & ap & at & at & ap & ap $* *$ & v3 \\
\hline $\begin{array}{l}\text { There is partial traceability of the product; only } \\
\text { when the product is defective, a permanent record } \\
\text { is created for traceability of the defect. }\end{array}$ & 0 & at & 0 & 0 & 0 & 0 & ap $* *$ & v2 \\
\hline $\begin{array}{l}\text { Manual annotations on tables to then be passed to } \\
\text { the system; no updates happen in real time; } \\
\text { tracking and registration are not automated; there is } \\
\text { no checklist or alert for overdue tasks. }\end{array}$ & ap & at & 0 & at & at & ap & ap ** & v2 \\
\hline
\end{tabular}

*synthesis of the diagnosis previously presented **the company folloes the Lean philosophy, however not all tools are being applied, characterizing the implementation process.

For the verification of proximity or distance in relation to the achievement of the selected objectives of the company by the sectors, a scale related to the level of compliance with the objective was used, where the variables were considered: (i) $0=$ not applicable (null value); (ii) na = not answered; (iii) ap = partially attended; (iv) at = fully answered. 
The scale previously described, led to the determination of guidelines for the type of change needed to put the theoretical issues raised into practice, classified based on the following variables with their application rules (correlated to meeting the objectives): (i) $\mathrm{v} 1=$ no change (rule: only at); (ii) $\mathrm{v} 2$ = weak positive change (rule: na + ap $\leq$ at); and (iii) $\mathrm{v} 3=$ considerable positive change (rule: $n a+a p>$ at).

Regarding the type of change, it is considered: v1 as no necessary change, as all objectives have been met; v2 as a weak necessary positive change, since in the relationship between the scale of meeting the objectives, most of them were met, that is, suggestions for improvements to be applied to the process will be made during the development of this project; v3 as a considerable necessary positive change, that is, points that must be considered for the design of the intelligent computational tool for diagnosis and analysis of product manufacture. The diagnosis of the production model presented aims to support the decisions to be made during the development of this project.

\section{Analysis of Results}

During the field survey it was verified that the stages of the production process are disconnected. In addition, decision making is based on snapshots that are often outdadet or inaccurate. The exchange of information between departaments, are avaliable in updated worksheets at the end of the day or in meetings at the beginning of the day. The techniques used to analyse operational data are isolated and without systematic linkage of criteria, that is, the updated information is not available in real time and is not connected and consequently making it impossible to have a holistic view of the whole production process. In relation to the traceability of information and materials, it is precarious and departamentalized, the information is not connected and lost at the end of each stage of the process, not being available to managers.

The diagnosis of the production model allowed to evaluate the type of change required in each sector of the company to guide the next steps of this project and to observe the gaps in the company's production process, directing the study towards the configuration of a model that represents the progress from the development of this project to the present moment, summarizing the main steps taken so far.

\section{Conclusion and Future Steps}

The research aims to identify the towards for a computational tool, with the goal is to improve the identification and analysis of nonconformities. Additionally, it is possible to identify opportunities to insert new technologies for product and process improvement alongside of the enterprise's production model. In this way, it was necessary to do an investigation in the management of all the processes of the company, in order to avoid the main problems that a research can face, such as the definition of the requirements for decision-making.

A complete mapping of all the existing activities of the production process was carried out. In addition to a diagnosis with assessment of the needs for changes in the process, which will be used as a reference by the computational tool during the implementation of the pilot system. In addition, recombinant innovation will be used to reuse and integrate resources that were not previously connected in the company and to deal with the dynamism of the business environment. The closed circuit principle aims 
to improve the performance of processes in relation to the time spent to close the cycle: connect, collect, analyze and act, controlling the activity in real time.

The next steps of this research include the selection of diagnostic tools and evaluation of the production process, definition of requirements and rules for decision making, analysis of project management platforms that are in accordance with the characteristics of the company to be carried out the migration for the new system without trauma for the company and the insertion of technology in the production process.

\section{Acknowledgments}

The authors would like to thank Pontifical Catholic University of Parana (PUCPR) and NHS Electronic Systems for the financial support to the development of this research.

\section{References}

[1] A. Gokhale, The digital frontier and the process industry. Hydrocarb Process. Houston; 2017;11-12,14-16.

[2] J. Mcmullen, L. Wiley Delivering Closed-Loop Business Operations for the Refinery Enterprise, Hydrocarb Process, Houston, 2017;I88-90.

[3] AC. Gil Métodos e técnicas de pesquisa social [Internet]. 6th ed. Ead. São Paulo: Editora Atlas S.A.; 2008. 216 p. Available from: http://books.google.com/books?id=T3BwPgAACAAJ\&pgis=1

[4] P.A.C. Miguel, A. Fleury, C.H.P. Mello, D.N. Nakano, E.P. de Lima, J.B. Turrioni, et al. Metodologia de pesquisa em engenharia de produção e gestão de operações. 2nd ed. Elsevier, Rio de Janeiro: ABEPRO; 2012. 260 p.

[5] E.C. Conforto, D.C. Amaral, S.L. da Silva, Roteiro para revisão bibliográfica sistemática: aplicação no desenvolvimento de produtos e gerenciamento de projetos. Cbgdp. 2011;8o CONGRES(12, 13 E 14 DE SETEMBRO DE 2011):1-12.

[6] L Shah, A. Etienne, A. Siadat, F. Vernadat, Decision-making in the manufacturing environment using a value-risk graph. J Intell Manuf., 2016;27(3):617-30.

[7] L. Qiao, Y. Qie, Z. Zhu, Y. Zhu, U. Zaman, N. Anwer An ontology-based modelling and reasoning framework for assembly sequence planning, Int J Adv Manuf Technol., 2018;94(9):4187-97.

[8] M. Malinauskiene, I. Kliopova, M. Slavickaite, J.K. Staniskis, Integrating resource criticality assessment into evaluation of cleaner production possibilities for increasing resource efficiency. Clean Technologies and Environmental Policy, 2016, Vol. 18, pp. 1333-44.

[9] D. Beverungen, H. Luttenberg, V. Wolf, Recombinant Service Systems Engineering. Bus Inf Syst Eng. 2018;60(5):377-91.

[10] C. Snider, S. Skec, J. Gopsill, B. Hicks, The characterisation of engineering activity through email communication and content dynamics, for support of engineering project management, Design Science, 2017;3, e22.

[11] D. Fleche, J.-B. Bluntzer, A. Al Khatib, M. Mahdjoub, J.-C. Sagot, Collaborative project: Evolution of computer-aided design data completeness as management information. Concurrent Engineering, 2017. Vol. 25, pp. 212-28.

[12] T. Seletos, J. Salmon, Analysis of Integrating a Production Design Generator with a Business Decision Support System for System-Level Decision Making, Systems, 2017;5(1):14.

[13] Q. Li, Q. Tang, I. Chan, H. Wei, Y. Pu, H. Jiang, et al. Smart manufacturing standardization: Architectures, reference models and standards framework. Comput Ind., 2018;101:91-106.

[14] B. Schneiderman, C. Plaisant, Designing the User Interface, 5th ed.; Addison Wesley: Boston, 2010.

[15] S.N. Samy, H. ElMaraghy, A model for measuring complexity of automated and hybrid assembly systems. Int J Adv Manuf Technol, 2012, 62(5):813-833.

[16] G. Ariav, M.J. Ginzberg, DSS Design: A Systemic View of Decision Support, Commun. ACM, 1985, 28, 1045-1052

[17] M. Toivonen, T. Tuominen Emergence of innovations in services, Serv Ind J, 2009, Vol. 29(7):887-902. https://doi.org/10.1080/02642060902749492

[18] F. Gallouj, O. Weinstein Innovation in services, Res Policy, 1997, 26(4/5):537

[19] P. Cooke, Four minutes to four years: the advantage of recombinant over specialized innovation - RIS3 versus 'Smart- spec'. Eur Plan Stud, 2016, 24:1494-1510 
[20] M. Wirth, S. Friesike, C. Flath, F. Thiesse Patterns of remixes or where do innovations come from: evidence from 3D printing. In: Proceedings of the 23rd European conference on information systems, Munster, 2015, paper 57. 